\title{
PELATIHAN KOMPUTER GRAFIS (ADOBE PHOTOSHOP) SEBAGAI UPAYA PENINGKATAN SOFTSKILL SISWA SMKS 21 QHAWAY SAHAB KOTA BENGKULU
}

\author{
Erlan Novijayanto ${ }^{1)}$, Wulandari ${ }^{2}$, Yolla Krismonika ${ }^{3)}$, Asnawati ${ }^{4)}$ \\ 1),2),3),4) Program Studi Sistem Informasi Fakultas Ilmu Komputer Universitas Dehasen Bengkulu \\ Jalan Meranti Raya No.32 Kelurahan Sawah Lebar Kota Bengkulu Kecamatan Ratu Agung 38228 \\ E-mail : erlanslow@gmail.com ${ }^{1)}$, wdari4075@gmail.com ${ }^{2)}$,yollakrismanonika1812@gmail.com ${ }^{3)}$, \\ sopian21@gmail.com ${ }^{4)}$
}

\begin{abstract}
ABSTRAK
Dalam menghadpi era perkembangan teknologi informasi maka sangat diperlukan suatu kemampuan (skill) yang memadai guna mendukung mutu siswa/siswi khususnya siswa/siswi di SMKS 21 Qhaway Sahab Kota Bengkulu. Tujuan dari kegiatan pengabdian kepada masyarakat adalah memberikan pengetahuan kepada siswa/siswi SMKS 21 Qhaway Sahab Kota Bengkulu mengenai Design Grafis dengan menggunakan aplikasi Adobe Photoshop dalam pembuatan Kartu Nama dan Flyer untuk meningkatkan kemampuan softskill siswa/siswi. Pelaksanaan kegiatan Pelatihan Komputer Grafis (Adobe Photoshop) di SMKS 21 Qhaway Sahab Kota Bengkulu berjalan dengan lancar dan baik, respon peserta terhadap pelaksanaan pelatihan termasuk dalam kategori sangat baik berdasarkan atas respon angket peserta pelatihan dan Pelaksanaan kegiatan berdampak dalam upaya peningkatan softskill bagi siswa/ peserta pelatihan.
\end{abstract}

Kata Kunci : Komputer Grafis; Desain; Photoshop.

\section{PENDAHULUAN}

Teknologi informasi komputer berkembang dengan pesat disegala aspek diantaranya apek ekonomi, aspek kesehatan, aspek sosial, aspek pendidikan dan aspek yang lainnya. Pada aspek pendidikan salah satunya aspek yang dirasakan sangat signifikan semua aktifitas dalam dunia pendidikan harus didampingi dengan sentuhan teknologi informasi yang mendukung kebijakan pemerintah tentang upaya untuk menempatkan pendidikan kejuruan yang mengisyaratkan bahwa arah pembinaan dan pengembangan berorientasi pada penyiapan Sumber Daya Manusia (SDM) atau tenaga kerja yang memiliki kompetensi dan daya saing untuk menghadapi era globalisasi.

SMKS 21 Qhaway Sahab Kota Bengkulu merupakan salah satu SMK swasta yang ada di Kota Bengkulu dengan tujuan mencerdaskan anak bangsa yang ada di Kota Bebgjuku. Dewasa ini semua bidang pekerjaan berbasis multimedia juga berkembang dengan cepat hal ini tentu disebabkan dengan perkembangan teknologi informasi khususnya komputer yang canggih dan murah yang harganya dapat dijangkau hampir seluruh lapisan masyarakat. Menurut Suyanto (2005) menyatakan multimedia adalah pemanfaatan komputer untuk membuat dan menggunakan teks, grafik, audio, dan gambar bergerak. Desain grafis adalah 
suatu bentuk komunikasi visual yang menggunakan gambar untuk menyampaikan informasiatau pesan seefektif mungkin. Dalam disain grafis, teks juga dianggap gambar karena merupakan hasil abstraksi simbol-simbol yang bias dibunyikan. Disain grafis diterapkan dalam disain komunikasi dan fine art. Seperti jenis disain lainnya, disain grafis dapat merujuk kepada proses pembuatan, metoda merancang, produk yang dihasilkan (rancangan), atau pun disiplinilmu yang digunakan (desain). Seni disain grafis mencakup kemampuan kognitif dan keterampilan visual, termasuk di dalamnya tipografi, ilustrasi, fotografi, pengolahan gambar, dan tataletak (Kusrianto : 2007).

Menurut Safanayong (2006) Adobe Photoshop merupakan program pengolah desain grafis yang familier danpaling diminati di kalangan desain grafis. Program ini dapat digunakan dengan mudah karena terdapat tool-tool maupun efek yang menghasilkan berbagai bentuk desain yang inovatif dan ekspresif dengan dilengkapi komposisi warna yang bagus,serta adanya tool untuk membuat objek yang unik dan kreatif. Desain grafis atau rancang grafis adalah proses komunikasi menggunakan elemen visual, seperti tulisan, bentuk, dan gambar yang dimaksudkan untuk menciptakan persepsi akan suatu pesan yang disampaikan (Lee W: 2004).

Menurut R. Wayne Mondy (2008) menyatakan bahwa pelatihan merupakan jantung dari upaya berkelanjutan untuk meningkatkan kompetensi, dalam melakukan pelatihan akan diperoleh pengetahuan dan keterampilan yang dibutuhkan untuk bekerja sehingga daya gunakan secara optimal. Dari hasil pengamatan yang dilakukan lulusan SMK untuk dapat bekerja cukup memiliki ijazah SMK ditambah dengan keterampilan kompetensi yang dimiliki oleh lulusan SMK. Penguasaan keterampilan merupakan syarat utama untuk dapat bekerja dalam semua bidang untuk saat ini. Hal ini disebabkan kurikulum SMK yang menyiapkan lulusan SMK siap terjun dunia kerja, dengan melalui kurikulum yang membentuk siswa/siswi memiliki jiwa yang siap menghadapi dunia kerja yang menuntut siswa/siswi untuk mengimplementasikan pengetahuan selama belajar dibangku sekolah. Selain pengetahuan yang sesuai dengan kurikulum di SMK juga terdapat upaya peningkatan Softskill siswa yang diwajibkan sekolah salah satunya adalah bidang multimedia. Hal tersebut juga terjadi di SMKS 21 Qhaway Sahab Kota Bengkulu dengan menindaklanjuti permintaan pengabdian masyarakat dari mahasiswa/mahasiswi Fakultas Ilmu Komputer untuk melakukan pengabdian kepada masyarakat di sekolah tersebut untuk melakukan pelatihan Komputer Grafis (Adobe Photoshop) khususnya dalam pembuatan kartu nama dan flyer dengan Adobe Photoshop.

Dengan latar belakang tersebut, dengan pemikiran dan tujuan meningkatkan kemampuan siswa/siswi SMK 21 Qhaway Sahab Kota Bengkulu setelah lulus SMK dengan mengikuti pelatihan design grafis, pada tataran praktis ini peserta lebih mudah memahami dan mengembangkan dasar-dasar Adobe Photoshop. Oleh karena itu, pelatihan Design Grafis yang mencakup penggunaan program untuk pembuatan dengan peningkatan keterampilan membuat kartu nama dan flyer bagi siswa yang masih duduk di bangku SMK. Sebagai tambahan bekal keterampilan selain perancangan layout desain gambar, tulisan dan foto, diberikan pengenalan dan pelatihan praktis bagaimana cara melakukan proses produksi mulai dari perancangan, penataan layout rancangan dan pencetakan pada media kertas. Dengan keterampilan tersebut maka lulusan SMKS 21 Qhaway Sahab Kota Bengkulu tidak akan kaget ketika memasuki dunia industri multimedia kreatif dan dapat jugadijadikan sebagai 
(Community Service in the Field of Science, Technology, and Agricultural)

Available online at : http://journal.pdmbengkulu.org/index.php/padamunegeri DOI: https://doi.org/10.37638/PadamuNegeri.1.1.1-7

bekal dasar dalam berwirausaha jika lulusan SMK berniat membuka usaha mandiri dalam bidang multimedia (Rahmawati : 2000).

\section{METODE}

Metode yang digunakan dalam kegiatan pengabdian masyarakat adalah metode demonstrasi. Metode demonstrasi digunakan untuk menyajikan materi dengan memperagakan melalui penjelasan teori mengenai materi mengolah dan membuat Logo, Stiker dan kartu nama dengan Aplikasi Adobe Photoshop CS6. Kemudian dilanjutkan dengan mempraktikan secara langsung. Praktek langsung dilakukan pada komputer masing-masing dalam mengimplementasikan tool-tool aplikasi Adobe Photoshop CS6.

Berdasarkan metode tersebut diatas maka tim pelaksanaan dan anggota tim melakukan kegiatan pelatihan komputer grafis (Adobe Photoshop) untuk memaksimalkan pemahaman dan mengembangkan minat sofskill siswa-siswi SMKS 21 Qhaway Sahab Kota Bengkulu. Sehingga diupayakan siswa-siswi dapat mengikuti kegiatan dengan baik. Dalam pelaksanaan kegiatan pengabdian ini dengan 9 langkah kegiatan dari menganalisis situasi dengan melakukan obeservasi ke SMKS 21 Qhaway Sahab Kota Bengkulu sampai dengan Analisis Hasil Pelatihan Komputer Grafis (Adobe Photoshop) seperti yang terlihat pada gambar 1.

\begin{tabular}{|l|l|}
\hline 1 & $\begin{array}{l}\text { - Observasi menganalisis situasi dengan melakukan kunjungan ke SMKS } 21 \text { Qhaway Sahab } \\
\text { Kota Bengkulu dan diskusi mengenai permasalahan \& Kebutuhan Mitra }\end{array}$ \\
\hline 2 & - Analisis dan Permasalahan SMKS 21 Qhaway Sahab Kota Bengkulu \\
\hline 3 & - Desain Solusi yang akan diberikan mengatasi permasalahan \\
\hline 4 & $\begin{array}{l}\text { - Penyampaian Materi dan demonstrasi Pembuatan Kartu Nama dan Flyer dengan } \\
\text { menggunakan Adobe Photoshop }\end{array}$ \\
\hline 5 & - Pendidikan dan Pelatihan Adobe Photoshop \\
\hline 6 & - Pembimbingan dan Pendampingan penugasan siswa dalam mengikuti kegiatan pelatihan \\
\hline 7 & - Diskusi dan Tanya Jawab antara instruktur dan Siswa \\
\hline & - Memonitoring dan evaluasi hasil implementasi photoshop dengan Kartu Nama dan Flyer \\
\hline & yang telah dikerjakan Siswa \\
\hline
\end{tabular}

Gambar 1. Langkah-langkah Kegiatan Pengabdian Masyarakat. 


\section{HASIL DAN PEMBAHASAN}

\section{A. Pelaksanaan Kegiatan}

Kegiatan Pelatihan Design Grafis dilaksanakan di ruang praktikum komputer / labor di SMKS 21 Qhaway Sahab Kota Bengkulu sebanyak 20 siswa yang mengikuti kegiatan ini dilaksanakan 1 hari pada hari Kamis tanggal 01 Oktober 2018 dari jam 08.00 wib s/d 14.00 wib. Kegiatan pelatihan berjalan lancar, kegiatan dari awal hingga akhir acara peserta mengikuti dengan baik. Melalui kegiatan ini siswa/siswi tidak hanya mempelajari materi mengenai pembelajaran, peserta juga diberi kesempatan praktik dengan studi kasus yang lain. Hal tersebut sangat membantu siswa/siswi dapat mengembangkan imajinasi setelah mengetahui materi dalam pelatihan ini selama kegiatan berlangsung seperti pada gambar 2 .

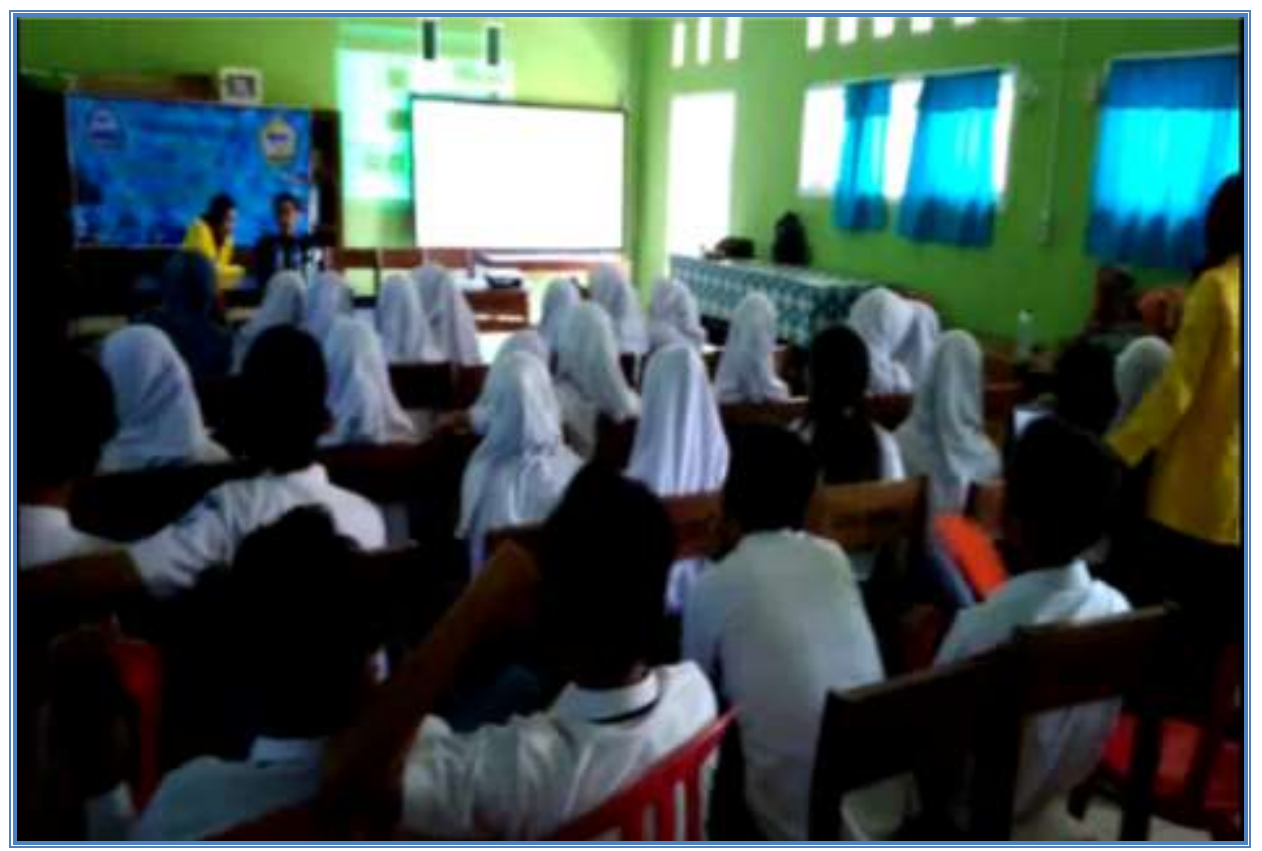

Gambar 2. Pelaksanaan Kegiatan Pelatihan Design Grafis

Adapun langkah-langkah yang telah ditempuh dalam kegiatan Pelatihan Design Grafis (Adobe Photoshop) ini mencakup beberapa tahap berikut ini :

1. Persiapan

Tahap persiapan meruapakan tahap awal dalam kegiatan pelatihan design grafis, tahap ini ada beberapa hal yang dilakukan seperti : a) menyusun susunan acara, b) mendesain konsep pelatihan, c) koordinasi dengan kepala sekolah dan guru mengenai tempat pelaksanaan kegiatan peatihan, d) penentuan dan rekruitment siswa/siswi sebagai peserta pelatihan, e) pembuatan modul/PPTppt/materi pelatihan, f) persiapan konsumsi, publikasi dan dokumentasi.

2. Pelaksanaan Pelatihan

Tahapan ini merupakan tahapan pelaksanaan kegiatan pelatihan design grafis (adobe photoshop) yang dilaksanakan di laboratorium SMKS 21 Qhaway Sahab Kota Bengkulu dengan mencakup beberapa hal sebagai berikut :

a. Penyampaian/penyajian/demonstrasi/praktik Materi

Materi yang disajikan terkait dengan pengenalan dan penggunaan aplikasi Adobe

Photoshop CS3 untuk pembuatan Kartu Nama dan Flyer.

b. Diskusi dan Tanya Jawab 
Tahapan diskusi dan tanya jawab dilakukan setelah penyampaian/ penyajian/ demonstrasi yang telah dilakukan oleh Tim Pengabdian kepada Masyarakat. siswa/siswi diberi kebebasan dengan bertanya dengan bahasa mereka sendiri dan Tim Pengabdian akan menjawab pertanyaan tersebut dengan pembuktian seperti dipraktikkan kembali.

c. Pembimbingan dan pendampingan penugasan siswa/siswi

Setelah selesai dalam memberikan materi, siswa/siswi diberikan tugas dengan didampingi dan dibimbing tim pengabdian kepada masyarakat serta memberikan solusi apabila timbul permasalahan selama penugasan.

3. Evaluasi kegiatan pelatihan

Evaluasi dilakukan setelah kegiatan pelatihan selesai dilaksanakan dengan menyebarkan kuisioner untuk 20 siswa/siswi sebagai peserta pelatihan. Dimana kuisioner terdiri dari tiga pertanyaan yaitu : a) Kualitas modul yang digunakan dalam penyajian materi, b) kualitas tim pengabdian kepada masyarakat mahasiswa/mahasiswi program studi Sistem Informasi FILKOM UNIVED, c) Persepsi siswa/siswi terhadap peningkatan pemahaman materi maupun membimbing dalam pelatihan.

4. Penutupan kegiatan pelatihan/pengabdian kepada masyarakat

Penutupan kegiatan dilakukan secara resmi yang dihadiri oleh kepala sekolah dan guru SMKS 21 Qhaway Sahab Kota Bengkulu, siswa/siswi peserta pelatihan, dosen pendamping kegiatan pengabdian kepada masyarakat dan tim pengabdian kepada masyarakat program studi Sistem Informasi FILKOM UNIVED.

\section{B. Evaluasi Kegiatan Pelatihn}

Secara umum kegiatan pengabdian ini berjalan dengan lancar, dimulai dari kegiatan survei, pendahuluan, pelaksanaan kegiatan pengabdian, sampai dengan pembuatan laporan kegiatan. Pelaksanaan kegiatan berjalan dengan lancar dapat terlihat dari peserta sangat aktif dalam diskusi kepada Tim Pegabdian Masyarakat atas materi-materi yang telah diberikan, begitupun dengan banyaknya pertanyaan yang dilontarkan pada saat sesi tanya-jawab kepada Tim Pengabdian Masyarakat. hal ini dikarenakan para peserta menyadari bahwa di era teknologi informsi ini kegiatan pembelajaran seperti ini dianggap sangat membantu siswa/siswi sebagai sarana pembelajaran yang dapat meningkatkan softskill siswa/siswi dalam membentuk lulusan yang siap pakai nantinya.

Melalui kegiatan pengabdian yang berkelanjutan akan terjalin kerjasama antara Program Studi Sistem Informasi FILKOM UNIVED dengan SMKS 21 Qhaway Sahab Kota Bengkulu dalam bidang lainnya yaitu pengembangan metode pembelajaran bagi guru-guru melalui penelitan dan pengabdian masyarakat dosen dan mahasiswa program studi Sistem Informasi FILKOM UNIVED.

Berdasarkan hasil angket Evaluasi dari pelaksanaan pelatihan Design Grafis (Adobe Photoshop) dalam kegiatan pengabdian masyarakat yang disebarkan pada kahir praktikum didapat beberapa data sebagai berikut : 


\section{Jurnal PADAMU NEGERI}

(Community Service in the Field of Science, Technology, and Agricultural)

Available online at : http://journal.pdmbengkulu.org/index.php/padamunegeri

DOI: https://doi.org/10.37638/PadamuNegeri.1.1.1-7

Tabel 1. Hasil Angket Evaluasi Kegiatan Pengabdian kepada Masyarakat

$-*$

a. Kualitas Modul yang digunakan

\begin{tabular}{|c|c|c|}
\hline Kriteria & Jumlah & Persentase $(\%)$ \\
\hline Sangat Baik & 20 & $100 \%$ \\
\hline Baik & 0 & $0 \%$ \\
\hline Rendah & 0 & $0 \%$ \\
\hline Sangat Rendah & 0 & $0 \%$ \\
\hline & Total & $100 \%$ \\
\hline
\end{tabular}

\begin{tabular}{|l|l|l|}
\hline \multicolumn{3}{|l|}{ b. Kualitas Pemateri/Tim Pengabdian kepada Masyarakat } \\
\hline Kriteria & Jumlah & Persentase (\%) \\
\hline Sangat Baik & 20 & $100 \%$ \\
\hline Baik & 0 & $0 \%$ \\
\hline Rendah & 0 & $0 \%$ \\
\hline Sangat Rendah & 0 & $0 \%$ \\
\hline & & $100 \%$ \\
\hline
\end{tabular}

c. Persepsi siswa/siswi terhadap peningkatan pemahaman materi maupun membimbing dalam pelatihan

\begin{tabular}{|l|l|l|}
\hline Kriteria & Jumlah & Persentase (\%) \\
\hline Sangat Baik & 20 & $100 \%$ \\
\hline Baik & 0 & $0 \%$ \\
\hline Rendah & 0 & $0 \%$ \\
\hline Sangat Rendah & 0 & $0 \%$ \\
\hline & & Total \\
& & $100 \%$ \\
\hline
\end{tabular}

Berdasarkan data dari tabel Tabel 1. Hasil Angket Evaluasi Kegiatan Pengabdian kepada Masyarakat Pelatihan Design Grafis (Adobe Photoshop) dapat disimpulkan tergolong sangat baik hal ini ditunjukkan jumlah 20 yang menunjukkan jumlah siswa/siswi yang mengikuti pelatihan memilih kriteri sangat baik atau sekitar $100 \%$.

Faktro-faktor yang mendukung pelaksanaan pengabdian sehingga dapat terlaksana dengan baik dan lancar sebagai berikut :

1. Terlaksananya pengabdian secara umum berjalan dengan baik dan lancar dengan dukungan kepala sekolah, guru dan siswa/siswi SMKS 21 Qhaway Sahab Kota Bengkulu dalam mendukung kegiatan pelatihan Design Grafis (Adobe Photoshop)

2. Di era pesatnya teknologi informasi, siswa/siswi harus bersikap cerdas dengan melihat peluang kesempatan pembelajaran tidak harus didapat dari guru saja tetapi dari media lainnya. 
3. Fasilitas dan semangat tim pengabdian kepada masyarakat program studi Sistem Informasi FILKOM UNIVED yang mendukung kelancaran pengabdian/pelatihan.

\section{KESIMPULAN DAN SARAN}

Kesimpulan yang dapat diambil dari kegiatan ini adalah : 1) Pelatihan Komputer Grafis (Adobe Photoshop) berjalan dengan lancar dan baik, 2) respon peserta terhadap pelaksanaan pelatihan Komputer Grafis (Adobe Photoshop) termasuk dalam kategori sangat baik berdasarkan atas respon angket peserta pelatihan dan 3) Pelaksanaan kegiatan berdampak dalam upaya peningkatan softskill bagi siswa/ peserta pelatihan komputer grafis (adobe photoshop)

Saran yang dapat direkomendasikan adalah : 1) melalui kegiatan pelatihan Komputer Grafis (Adobe Photoshop) dapat dikembangkan lagi menjadi media pembelajaran yang dapat meningkatkan minat belajar peserta didik, 2) perlu adanya dukungan materil ataupun non materil untuk transportasi peserta dalam mengikuti pelatihan.

\section{UCAPAN TERIMA KASIH}

Terimakasih terutama kepada Kepala Sekolah SMKS 21 Qhaway Sahab Kota Bengkulu yang telah memberikan izin atas terlaksananya kegiatan pengabdian kepada masyarakat dengan memberikan pelatihan komputer grafis (Adobe Photoshop) bagi siswasiswi dan juga terimakasih kepada Ketua LPPM Universitas Dehasen dan Dekan Fakultas Ilmu Komputer dan Ketua Program Studi Sistem Informasi dan Dosen Tetap Program Studi Sistem Informasi Universitas Dehasen Bengkulu yang telah mengorganisir demi kelancaran kegiatan ini.

\section{DAFTAR PUSTAKA}

Kusrianto, A. 2007. Pengantar Desain Komunikasi Visual. Andi, Yogyakarta.

Lee, William L, 2004. Multimedia based instructional design: secon edition. San Fransisco. Preiffer.

Mondy R Wayne. 2008. Manajemen Sumber Daya Manusia. Jakarta : Erlangga.

Rahmawati. 2000. Pendidikan Wirausaha dalam Globalisasi. Yogyakarta. Liberty.

Safanayong, Y. 2006. Desain Komunikasi Visual Terpadu. Jakarta: Arte Intermedia.

Suyanto. 2005. Multimedia : untuk meningkatkan keunggulan bersaing. Yogyakarta : Penerbit Andi Offset. 